\title{
The Impact of Personal Characteristics on Personal Branding in Reflection to the Employability
}

\author{
Prassanna Pathmanathan, Nadeeja Dodamgoda \\ Imperial Institute of Higher Education Colombo, Sri Lanka \\ prassanna@ultimmatraining.com, nadeejadd@yahoo.com
}

\begin{abstract}
Unemployment is a major problem Sri Lanka is facing over the years. Although 22,000 graduates pass out every year from state and private universities, there is always a gap between what employers expect in a graduate and what the graduate could offer to the employer. This research focus on the employability of the IT graduates passing out from state and private universities, with specific reference to their personal characteristics and personal branding. Personal branding is a major concern with respect to the recruitment of any graduate. IT graduates especially are expected to have certain personal characteristics which determine their personal branding and influence their employability. The main objective of this research is to determine the impact of the personal characteristics such as personal identity, personal image and personal positioning on employability of IT graduates and to analyze their mediation effect with the personal branding. Further, an attempt is made to determine whether the personal branding and employability of IT graduates significantly differ based on the university type (state and private). The research mainly focuses on quantitative analysis by piloting a questionnaire to 300 IT graduates following a hypothetical deductive method. The findings through the quantitative data are followed up based on qualitative data collected through semi-structured interviews with HR and Recruitment Managers of IT companies. Findings of this research revealed that personal characteristics have a strong impact on the employability of an IT graduate and this relationship is mediated by personal branding. Further, IT graduates passing out from private sector universities have stronger personal characteristics and personal branding compared to the graduates passing out from state sector universities. Thus, they are more employable compared to IT graduates passing out from state sector universities in Sri Lanka.
\end{abstract}

Keywords: Personal branding, Employability, Personal identity, Personal image, Personal positioning

\section{Introduction}

As economic growth in Sri Lanka has been amongst the fastest in South Asia in recent years, several employment opportunities emerge regularly and the demand for professionals has risen. The current primary and secondary education enrolment rates of Sri Lanka are $98 \%$ and $97 \%$ respectively, which are quite high for a developing economy (Kapurubandara, 2016). There are 18 state universities in Sri Lanka with an annual intake of about 22,000 students per year and the annual graduate output is around 20,000 per annum. Although the graduates passing out from the state Universities is in the rising level, still the unemployment rate of Sri Lanka is alarming (Dissanayake, 2014). According to Unemployed Graduate Association there are around 42,000 graduates who are unemployed in Sri Lanka (Srilankamirror.com, 2016). According to Kapurubandara (2016), even though the "overall unemployment rate is 4.6\% in 2016; the unemployed rate of the educated is a disturbing $10.1 \%$. The numbers are even more disconcerting as the unemployment rate of the overall youth (15-29 years), is $27.3 \%$ for the same period". With the growing economy, although enough jobs are created for university graduates, the challenge for the employers is finding the right workers as most graduates lack soft skills and workforce skills (Dissanayake, 2014). Thus, the question arises as to why such a situation transpired.

Many explanations are given for unemployment among the educated youth in Sri Lanka. The most wellknown is that there is a skills mismatch, owing to the education system not harnessing the skills required by the job market (Sanderatne, 2011). Companies nowadays weigh applicants' "personal characteristics" just as heavily as they weigh core job capabilities and traditional qualifications (Miester, 2012). Applicants with strong personal characteristics and personal branding have an advantage in the recruiting process and the potential of standing out (Paul, 2012). Personal characteristics of a graduate such as personality, professionalism, self-confidence, good appearance, etiquettes, behavior, networking, communication skills, non-verbal behavior and other soft skills get them jobs very easily (Tharamaseelan, 2007). Schawbel (2010) stated that personal branding is the process by which the individuals differentiate themselves from the others and be at the forefront of others. A person can be distinguished by key factors such as his/her behavior, 
personality, leadership, charisma, team working and interpersonal skills. Many young professionals lack training in vital 'soft skills' which lead to difficulty in building a personal brand (Towson, 2015). It is corroborated with the lack of exposure and not having proper mentorship. Lack of a personal brand compels young graduates to engage in an occupation after graduation, which does not meet their expectations.

The absence of a powerful personal brand, bars the chances of generating new opportunities for a person resulting the majority to settle for any job which comes their way even for a lower salary. Some remain unemployed for a long time. The disappointment can backlash as frustration, youth unrest and other forms of anti-social behaviors (Ariyawansa, 2008, p. 92). In the above circumstances, the concept of personal branding needs to be compulsorily, to be implemented amongst young graduates. Research conducted in the field of personal branding is insufficient as the previous surveys and researches have not given adequate attention to the practical challenges faced by graduates in conjunction with employment (Parmentier, Fischer, \& Reuber, 2012). This study takes an approach to discuss the phenomenon of personal branding whilst focusing on the problems pertaining to personal branding of graduates. The ultimate objective of the current study is to assist fresh graduates in molding themselves to be "employment-worthy" in an attention.

The IT industry which is a growing industry in Sri Lanka with a contribution of 56.6 percent to the GDP, recording a positive growth rate of 4.5 percent during the second quarter of 2017 (Gunatatna, 2017) is a high demanding area for graduates. IT companies always look for the best personal characteristics of IT graduates compared to most of the other industries since clients of most of the Sri Lankan IT Companies are based in other countries. The state and private universities produce thousands of IT graduates every year thus, enhancing personal characteristics and personal branding skills of graduates to suit the demands of employers is important. Positive personal characteristics of a graduate is looked at very seriously when his/her personal branding is concerned. This enables the graduates to be employed with good perks and promotions in the future. Unemployment is alarming for graduates in Sri Lanka and it is a serious research problem that needs to be taken into consideration to understand whether there is an association between these personal characteristics and personal branding in reflection to the employability of graduates.

\section{Literature Review}

Personal Branding: The prevailing school of thought as to 'what is personal branding' is that it generally "entails capturing and promoting an individual's strengths and uniqueness to a target audience" (Sullaivan, Lair, \& Cheney, 2005). However, personal branding is not about merely vending a graduate at a job interview or to a target audience. Young professionals can use their personal brands to enhance their recognition as experts in their fields, establish reputation and credibility, advance their careers, and build self-confidence by identifying their unique value proposition and then leveraging it across platforms with a consistent message and image to achieve a specific goal.

\section{Elements of Personal Branding}

Personal Appearance: Creating the best first impression is crucial for building one's personal brand which includes their clothing, hygiene, style and attractiveness. Research shows that it takes only six seconds to create an impression about a person (Weiss \& Felderman, 2006). This personal appearance impacts a person facing a job interview, appearing at a conference, networking with business professionals etc.

Personality: Personality is defined as the combined characteristics of qualities that form an individual's distinct character (Montoya, 2002). Personality defines how well a person behaves, his/her etiquettes, mannerisms etc. In addition, it determines the values, goals, identity and behavior of a person. If graduates are well aware of their personality traits it is easy for them to approach corporate effectively and also it helps them to get their dream jobs.

Competencies: Having the best personality and good personal appearance alone does not help one to develop his/her personal branding. Skills, knowledge and abilities are very important to stand out from the rest and to gain competitive advantage. Competencies in personal branding include cognitive, business, communication and technical skills that enable the person to perform their job responsibilities (Labrecque et 
al., 2011). When creating a personal branding strategy there are few areas a person should consider (Usrey \& Sargent, 2013). These can be related to the IT graduates as follows:

The Strengths: The graduate should know what his /her strengths are and what he/she is known for. This can be in the areas of academic achievements, work experience, sports skills etc.

Passions: The areas the graduate is passionate about and what sets him/her apart from the other graduates. Passions include various elements of interest one might have.

Accomplishment: This determines what the accomplishments the graduate wants to achieve in his/her career and how he/she is planning to do it.

Success: How well the success can be defined and the elements of success.

Personal Branding Models: According to Authentic Personal Branding model of (Rampersad, 2011), personal brand of a person should reflect his/her true character and should be built on their strengths, values uniqueness and genius. As shown in the below figure this model consists of four wheels which are interrelated and need to turn in the right direction in order to get the large personal branding wheel moving and evolving in the right direction successfully.

Figure 1: Authentic personal branding model (Rampersad, 2011)

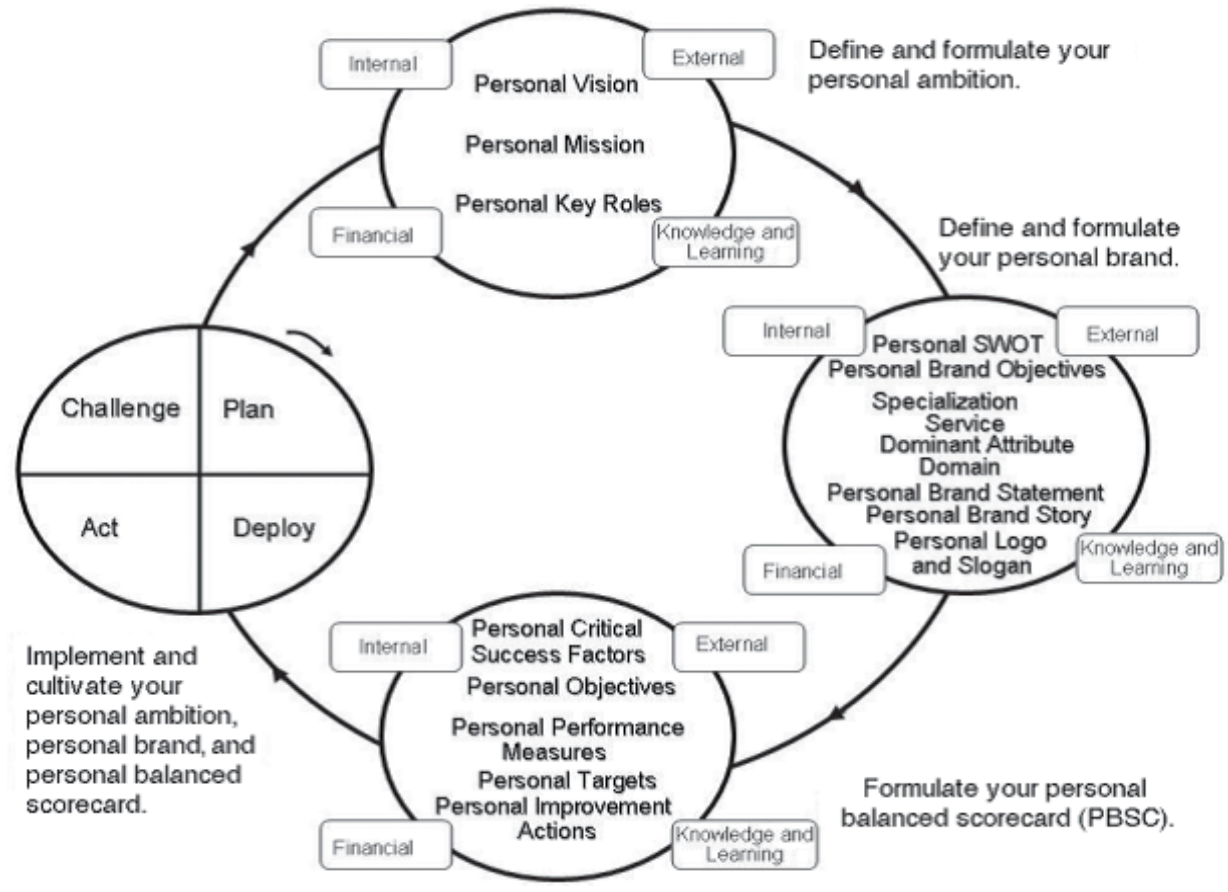

The main four phases of the authentic personal brand model are as follows;

Define and Formulate the Personal Ambition: This phase includes definition and the formulation of personal ambition of a young professional. It should incorporate the personal vision, mission and key roles of a graduate, linked to four perspectives which should be in balance; internal, external, knowledge and learning and financial which keep a balance between the personal brand and the lifestyle (Rampersad, 2011).

Define and Formulate the Personal Brand: This phase comprises defining and formulating an authentic and compelling personal brand. According to Rampersad (2011), one should conduct a SWOT analysis of him/herself initially. The results of this analysis define of one's lifestyle. This relates to the personal brand ambition and the personal brand objectives. 
Formulate Personal Balance Scorecard: This stage includes developing and integrating a well-balanced action plan based on the personal ambition and the personal brand to achieve the personal brand objectives. This plan should be adhered into the four perspectives. According to Rampersad (2011) this process is essential to let the brand awareness of a person to grow gradually. In overall this model can be identified as a very informative personal branding model for a graduate to start up the personal branding process.

Implement and cultivate personal ambition, brand and Personal Balance Scorecard (PBSC): This phase includes implementing, maintaining and cultivating the personal ambition, brand and the PBSC effectively. To guide people in this process a unique learning cycle called the 'Plan, Deploy, Act, Challenge' cycle (PDAC) is integrated to this model which should be followed continuously. According to Rampersad (2011) this process is essential to let the brand awareness of a person to grow gradually. In overall this model can be identified as a very informative personal branding model for a graduate to start up the personal branding process. However, one shortcoming of this model is, it doesn't describe about the factors affecting the personal brand of a person and the indicators of those factors.

Factors Affecting Personal Branding of Graduates: The self-concept theory (the totality of believes, preferences, opinions and attitudes organized in a systematic way towards personal existence), identifies that people behave in multiple ways to enhance and maintain themselves (Hollenbeck \& Kaikati, 2012). However, the three factors named personal brand identity, brand image and the brand positioning which is commonly known as personal characteristics are the key components of a personal brand in securing employability of a young graduate. For a successful personal brand, all three factors must be maintained in equally good condition. Therefore, it is essential that a graduate is mindful as to how it could affect the personal brand when seeking employment.

Personal Identity: The personal identity is one of the most important factors in building a powerful personal brand for a professional (Labrecque et al., 2011). It can be described as to how the target employers perceive a young professional's personal brand. The personal identity is what solidifies the objective of the personal brand of graduates. Hillgren et al. (2011) support this position as they state that the personal identity is what clarifies and stimulates the true cause and aim of a personal brand. The personal identity is like the concept of human identity (Shepherd, 2005). Hence the personal identity of a graduate is clearly indicated by his/her personality traits, authentic behavior, professionalism and self-efficacy.

Personal Image: The personal image is heavily based on its visibility, but it is not confined to the outward appearance or the presentation of a person. The personal image is reflected in non-verbal behavior, attitude and business etiquette (Labrecque et al., 2011; Schawbel, 2010) Relating the findings to the IT graduates, the personal brand image is the first impression of a graduate formed in the mind of an employer at the first point of contact. It is also the first perception conceived in the employers' mind about the graduate's personal brand itself (Labrecque et al., 2011). Therefore, graduates must pay extra attention to their personal brand image to maintain the personal image up to job market standards.

Personal Positioning: Once the personal identity is established and the corresponding personal image is projected to an audience, the personal brand needs to find its position within the society, market and audience. Personal positioning is a process to generate a desired personal brand reflecting the personal identity and personal image (Aaker, 2002) leading a person to "stand out". Personal positioning should be used to highlight positive attributes which are valuable for the employers by differentiating from the peers (Labrecque et al., 2011). Many indicators are found to be related to personal positioning such as networking, elevator pitch and impression management (Labrecque, et al., 2011).

Aligning Personal Branding with Corporate Branding: In order to align the personal brand of an employee with the corporate brand, first of all the personal vision, mission and objectives of the employee should be matched to the corporate vision, mission and objectives. Therefore, finding a way to overlap personal and corporate goals is critical. This is needed because employees don't work with their full potential or expend energy on something they do not believe in. If there is a direct match between the interests of the employees and the company interests or if the employees' values are aligned with organization's values and beliefs, they will be engaged and work with greater commitment and dedication to meet company objectives. When the 
personal brands of employees in the organization are compatible with corporate's brand and aligned in best interests of both parties, the outcomes will be high brand equity, brand loyalty for the corporate brand and happy stakeholders (Rampersad, 2011). Aligning personal brand with the corporate brand has an effective impact on the organizational bonding of the employees. This process energizers the employees of the organization and they make a useful and valuable contribution to the organization's performance. Therefore, it has become essential to get the optimal fit of employee personal brand and corporate brand to increase employee productivity, engagement, commitment, passion and love to the company (Rampersad, 2011).

\section{Research Methodology}

Conceptual Framework: The conceptual framework is the foundation on which the whole research is based on. It is a logically developed, defined and explained network of associations among the variables considered relevant to the problem domain. It is identified through processes such as observations, interviews and literature review. Therefore, from the university level and higher education level there are certain changes recommended. The Universities should include modules such as personal branding, professional practice and interpersonal skills in the university curriculum. They should make industrial placement compulsory for students in a way they will get one-year work experience before they pass out as IT graduates.

Figure 2: Conceptual Framework developed by the authors

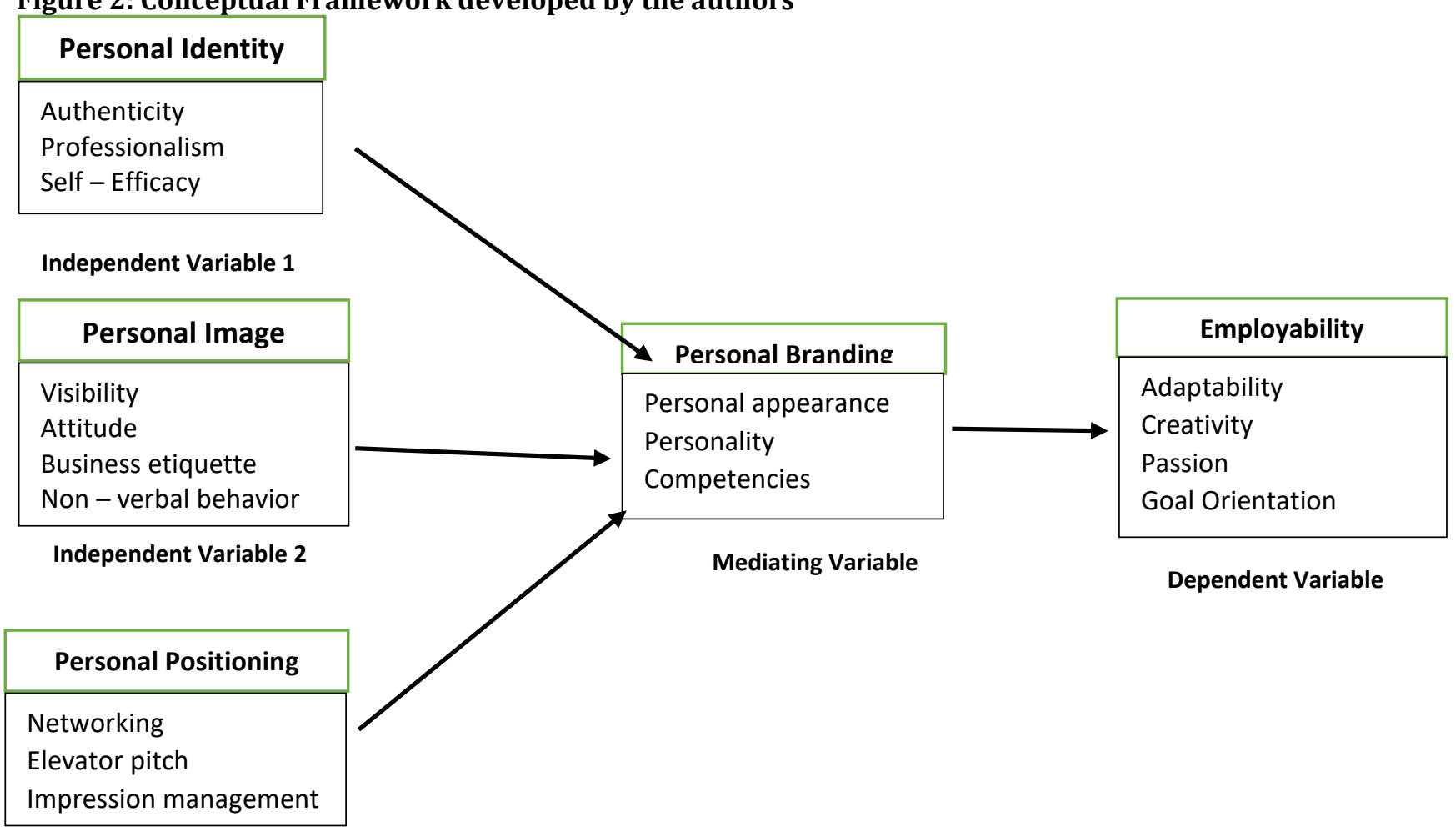

Independent Variable 3

Based on the literature, there are three independent variables that have a major influence on the employability through a mediating variable personal branding. According to the literature review three independent variables are identified such as personal identity, personal image and personal positioning. These three variables are considered critical for an IT graduate to build his/her personal brand in return to gain the employability in the corporate environment. Five hypotheses were formed using a deductive approach to test the relationship between the independent variable and the dependent variable. Moreover, two more hypotheses were formed testing the mediating effect on the relationship between the independent variable and the dependent variables and the significance of the difference in the employability of graduates passing out from state and private sector universities. 


\section{Hypothesis 1}

H1. A: Personal identity has a positive relationship with employability.

H1. O: Personal identity has no relationship with employability.

\section{Hypothesis 2}

H2. A: Personal image has a positive relationship with employability.

H2. O: Personal image has no relationship on employability.

\section{Hypothesis 3}

H3. A: Personal positioning has a positive relationship with employability.

H3. O: Personal positioning has no relationship on employability.

\section{Hypothesis 4}

H4. A: Personal branding mediates the relationship between the personal characteristics and the employability.

H4. O: Personal branding does not mediate the relationship between the personal characteristics and the employability.

\section{Hypothesis 5}

H5. A: There is a significant difference in the employability of the IT graduates passing out from the state and private sector universities.

H5.0: There is no significant difference in the employability of the IT graduates passing out from the state and private sector universities.

Research Approach and Methodology: Based on the Research Onion framework by Saunders, Lewis, \& Thornhill (2013) this research follows a pragmatic philosophy where the research focuses on answering the research question "What is the impact of personal characteristics reflected through personal branding on the employability of IT graduates?". This research mainly follows a deductive approach thereby, testing the existing theory on personal branding with the follow up of interview findings. Hence, including an inductive approach with less emphasis compared to the deductive method of piloting a questionnaire among 300 IT graduates. The research strategy was mainly a survey with a cross-sectional time horizon as data was collected only once. The researcher has adopted a mixed method with more emphasis on quantitative data, where the study can be categorized as the explanatory mixed method according to Cresswell (2014). The questionnaire for the IT graduates consisted of questions testing the personal characteristics, personal branding and the employability, where questions were on the five-point Likert scale with answers ranging from 1 (strongly disagree) to 5 (Strongly agree). A high score for any question indicates a high level of each indicator tested. Findings from the quantitative analysis were followed up with semi-structured interviews with managers often IT companies. The target population for the quantitative study were the IT graduates who have passed out from the universities and are employed in their first job as graduates.

\section{Findings}

Reliability and Validity Testing of the Variables: As the initial step, the dimensions of personal characteristics were tested for uni-dimensiality by performing factor analysis. The results implied that the responses can be grouped into the three dimensions of personal characteristics; Personal Identity (PIN), Personal Image (PIM) and Personal Positioning (PPO). The questions under each dimension was coed with the abbreviation of the dimension and the question number, for example question 4 of personal identity as PIN4. The data was further tested for convergent validity, discriminant validity and the reliability. 
Table 1: Rotated Component Matrix.

\begin{tabular}{|l|r|r|r|}
\multicolumn{5}{c|}{ Rotated Component Matrix } \\
\hline & \multicolumn{3}{|c|}{ Component } \\
\hline & 1 & 2 & \multicolumn{1}{c|}{3} \\
\hline PIM5 & .774 & & \\
PIM8 & .752 & & \\
PIM6 & .752 & & \\
PIM7 & .714 & & \\
PIM4 & .713 & & \\
PIM3 & .712 & & \\
PIM1 & .711 & & \\
PPO4 & & .780 & \\
PPO5 & & .750 & \\
PPO2 & & .693 & \\
PPO3 & & .657 & \\
PPO6 & & .618 & \\
PPO1 & & .596 & \\
PIN5 & & & .745 \\
PIN3 & & & .731 \\
PIN2 & & & .599 \\
PIN4 & & & \\
PIN1 & & & .550 \\
\hline
\end{tabular}

Extraction Method: Principal Component Analysis.

Rotation Method: Varimax with Kaiser Normalization.

a. Rotation converged in 6 iterations.

The convergent validity of a construct can be ensured by having the Average Variance Explained (AVE) of the construct greater than 0.5 and Composite Reliability of each construct greater than 0.7 . The discriminant validity can be verified by having the AVE of each latent construct greater than the highest squared correlation with any other latent construct (Hair, Christian, \& Marco, 2011). Further, Kaiser - Meyer - Olkin measure of sampling adequacy (KMO) and Bartlett's test of Sphericity are two good techniques that are applied to test factorability of data. KMO values above 0.5 indicate acceptable levels of factorability of data. The reliability of the measurements can be accepted as good if the Cronbach's Alpha is greater than .07 (Sekeran \& Bougie, 2016). The study results are shown in the tables 2 and 3 indicate that the independent, mediating and dependent variables were well within the parameters for reliability and validity.

Table 2: Results of Discriminant Validity Test (Researcher Constructed)

\begin{tabular}{|c|c|c|c|c|}
\hline & & $\begin{array}{l}\text { Personal } \\
\text { Identity }\end{array}$ & $\begin{array}{l}\text { Personal } \\
\text { Image }\end{array}$ & $\begin{array}{l}\text { Personal } \\
\text { Positioning }\end{array}$ \\
\hline \multicolumn{2}{|c|}{ Personal Identity } & \multicolumn{3}{|l|}{ AVE $=0.51$} \\
\hline \multirow{2}{*}{$\begin{array}{l}\text { Personal } \\
\text { Image }\end{array}$} & Pearson Correlation & 0.583 & \multicolumn{2}{|l|}{$\mathrm{AVE}=0.62$} \\
\hline & Squared Correlation & 0.34 & & \\
\hline Personal & Pearson Correlation & 0.596 & 0.711 & $\mathrm{AVE}=064$ \\
\hline Positioning & Squared Correlation & 0.355 & 0.506 & \\
\hline
\end{tabular}


Table 3: Results of Convergent Validity Tests (Researcher Constructed)

\begin{tabular}{|c|c|c|c|c|c|}
\hline Variable & Cronbach's alpha & KMO & Bartlett's test & AVE & CR \\
\hline Rule of thumb & $>0.7$ & $>0.5$ & Sig. $<0.05$ & $>0.5$ & $>0.7$ \\
\hline \multicolumn{6}{|l|}{ Independent Variable } \\
\hline Personal Identity & 0.702 & 0.784 & $\begin{array}{l}\chi^{2}=299.61 \\
\text { Sig: } .000\end{array}$ & 0.51 & 0.83 \\
\hline Personal Image & 0.900 & 0.896 & $\begin{array}{l}\chi^{2}=1060.89 \\
\text { Sig: } 0.000\end{array}$ & 0.62 & 0.92 \\
\hline Personal Positioning & 0.858 & 0.882 & $\begin{array}{l}\chi^{2}=908.59 \\
\text { Sig: } .000\end{array}$ & 0.64 & 0.91 \\
\hline \multicolumn{6}{|l|}{ Mediating Variable } \\
\hline Personal Branding & 0.839 & 0.820 & $\begin{array}{l}X^{2}=685.95 \\
\text { Sig: } .000\end{array}$ & 0.57 & 0.88 \\
\hline \multicolumn{6}{|l|}{ Dependent Variable } \\
\hline Employability & 0.795 & 0.840 & $\begin{array}{l}X^{2}=538.10 \\
\text { Sig: } .000\end{array}$ & 0.53 & 0.87 \\
\hline
\end{tabular}

Analysis of personal characteristics and Personal Branding: The quantitative data collected through the questionnaire were compiled to calculate the average scores earned by each graduate for each of the variables tested in the study. The scores were analyzed based on the university type, as shown in table 3 below.

Table 4: Comparison of Personal Characteristics and Personal Branding Based on University Type (Researcher Constructed)

\begin{tabular}{lll}
\hline Variable & State University Graduates & Private University Graduates \\
\hline Personal Positioning & 3.02 & 3.65 \\
Personal Image & 3.48 & 4.06 \\
Personal Identity & 3.19 & 3.75 \\
Personal Branding & 3.30 & 3.85 \\
\hline
\end{tabular}

The above results clearly indicate that Graduates passing out from private sector universities are stronger in personal characteristics and personal branding compared to the state sector IT graduates.

Testing of Hypotheses: Five hypotheses were formed in this research and the first three hypotheses were to test the relationship between the independent variable and the dependent variable. This was tested using the Person's correlation coefficient and regression coefficient. The fourth hypothesis was to test the mediating effect of personal branding on the relationship between personal characteristics and employability. Sobel test calculator results were used to test this hypothesis. The fifth hypothesis was to check the significance of the difference in the employability of the IT graduates passing out from the state and private sector universities and independent sample t-test is used to prove the fifth hypotheses.

\section{Testing of Hypothesis 1, 2 and 3}

Table 5: Results of Tested Hypotheses 1,2 and 3(Researcher constructed)

\begin{tabular}{|c|c|c|c|c|}
\hline Hypotheses & Variables Constructed & $\begin{array}{l}\text { Pearson } \\
\text { Correlation }\end{array}$ & $\begin{array}{c}\text { Significance of } \\
\text { Correlation at } 0.1 \text { sig level }\end{array}$ & $\begin{array}{l}\text { Results of the } \\
\text { Hypotheses }\end{array}$ \\
\hline H1.A: & Relationship between Personal & 0.610 & Significant & H1.0 rejected \\
\hline $\begin{array}{l}\text { H2.A: } \\
\text { H2.0: }\end{array}$ & $\begin{array}{l}\text { Relationship between Personal } \\
\text { Image and Employability }\end{array}$ & 0.735 & Significant & H2.0 rejected \\
\hline $\begin{array}{l}\text { H3.A: } \\
\text { H3.0: }\end{array}$ & $\begin{array}{l}\text { Relationship between Personal } \\
\text { positioning and Employability }\end{array}$ & 0.721 & Significant & H3.0 rejected \\
\hline
\end{tabular}


From the above table it is proven that null hypothesis with respect to Hypotheses 1,2 and 3 are rejected and the relationships are significant.

In addition to the above correlation test, a multiple regression model was conducted to understand more about the combined effect of the three independent variables (personal characteristics) on the dependent variable.

Table 6: Model Summary Results of Multiple Regression (Researcher constructed)

Model Summary

\begin{tabular}{lllll}
\hline Model & $\mathrm{R}$ & R Square & Adjusted R Square & Std. Error of the Estimate \\
\hline 1 & $.800^{\mathrm{a}}$ & .640 & .636 & .41421
\end{tabular}

a. Predictors: (Constant), Personal identity, personal image, personal positioning. This multiple regression analysis clearly shows the significance of the influence of personal characteristics on the employability of Sri Lankan IT graduates. The results show that the coefficient of determination $\left(\mathrm{R}^{2}\right)$ is 0.640 (Adjusted $\mathrm{R}$ square $=$ $0.636)$. Hence, it shows that $63 \%$ of the variation in employability is explained through variations in the personal characteristics of the IT graduates.

Table 7: The Regression Coefficients 00(Researcher constructed) Coefficients $^{\mathbf{a}}$

\begin{tabular}{lllllll}
\hline & & \multicolumn{2}{l}{$\begin{array}{l}\text { Unstandardized } \\
\text { Coefficients }\end{array}$} & $\begin{array}{l}\text { Standardized } \\
\text { Coefficients }\end{array}$ & \\
Model & & B & Std. Error & Beta & T & Sig. \\
\hline 1 & & .934 & .131 & & 7.109 & .000 \\
& (Constant) & .168 & .042 & .183 & 4.049 & .000 \\
& Personal Identity & .336 & .044 & .391 & 7.559 & .000 \\
& Personal Image & .281 & .044 & .334 & 6.373 & .000 \\
& Personal Positioning & & & & & \\
a. Dependent Variable: Employability & & & & &
\end{tabular}

The table shown above covers the independent variables of personal identity, personal image and personal positioning. The coefficient table above shows all three independent variables are significant at 0.05 significance level. Therefore, all of them have a significant impact on the employability. The multiple regression equation could be explained as follows: Employability $=0.934+0.168$ (PIN Mean) +0.336 (PIM Mean) + 0.281 (PPO Mean), This equation could be actually used in hiring IT graduates in IT companies where based on a questionnaire that is developed to check the personal characteristics can be given to the IT graduates and the mean of personal identity, personal image and personal positioning can be substituted to the equation given above to calculate the employability level of the IT graduate to be employed at the IT organization.

\section{Testing of Hypothesis 4}

Table 8: Results of Sobel Test for Mediation Effect (Researcher constructed)

Sobel Test Statistics p-value Significance

\begin{tabular}{lllc}
\hline $\begin{array}{l}\text { Mediation of personal branding on personal identity } \\
\text { and employability }\end{array}$ & 9.529 & 0.000 & Significant \\
$\begin{array}{l}\text { Mediation of personal branding on personal image and } \\
\text { employability }\end{array}$ & 7.506 & 0.000 & Significant \\
$\begin{array}{l}\text { Mediation of personal branding on personal positioning } \\
\text { and employability }\end{array}$ & 8.283 & 0.000 & Significant
\end{tabular}


The mediation effect was tested using the Sobel test. The alternative hypotheses were selected by rejecting the null hypotheses because of the Sobel test results have all p-values below the 0.05 threshold.

Testing of Hypothesis 5: The alternative hypotheses were selected in this test by rejecting the null hypotheses because in the independent sample t-test is indicating a significant difference between the means of employability of the two populations (state and private university graduates). Sig. $(2-$ tailed) $=0.000$. Therefore, there is a significant difference in the employability of the IT graduates passing out from the state and private sector universities.

Qualitative study: Ten HR heads and recruitment managers were interviewed from 10 selected IT companies in Colombo for the qualitative study. The interviews were based on the importance of the personal characteristics (independent variables) such as personal identity, personal image and personal positioning in securing employability. Then the interviews also inquired about the effect of mediating variable personal branding on the independent and dependent variable relationship. The importance of these variables for the IT graduates in securing a job was analyzed separately and also the significance of the difference in the employability of the IT graduates of state and Private Sector Universities was also determined separately.

Findings on the Personal Identity: All the respondents (100\%) agreed that personal identity is a very important factor for the IT graduates to secure employability in their respective IT companies. They all stated that personal identity footprint gives a considerable advantage not only for recruitment of the IT graduates but for the career progression in carrying up them in the organizational hierarchy. Respondents also stated that the right qualifications and experiences alone will not help the IT graduates to secure their jobs. Personal identity plays a major role in getting them their dream job in their favorite company. $30 \%$ of the respondents stated state university IT graduates are best in their personal identity where $70 \%$ of the respondents felt private university IT graduates are better.

Findings on the Personal Image: All respondents agreed that personal image expands a graduate's exposure in an organization and it helps IT graduates to secure their employment in a very positive way. The respondents stated that if the personal image is positive then the chances of the IT graduate getting exposed to various different job roles in the company is quite high. Further, the personal image also expands opportunities for their job rotation, job enlargement and job enrichment. Management is confident to give more responsibilities to an IT graduate who has a positive personal image. After the Curriculum Vitae, the next most important juncture for an employer to choose an employee is the few minutes that they get with the candidate in the form of an interview. Hence, it is of utmost importance that the candidate presents him / herself to the best of their ability. The employers are interested in the technical know-how of the candidate but at the same time they keep a close eye on the appearance, body language and attitude of the person especially if the company needs its employees to interact with external customers / stakeholders. Personal image in this case helps the candidate to secure his/her job and move up in the career ladder.

Findings on the Personal Positioning: Personal positioning comprises rate and willingness to network, mingling proficiency, convincing ability and public speaking ability. All the respondents (100\%) agreed that personal positioning is an essential element for young IT graduates in gaining employability. Personal positioning helps the IT graduate to create a positioning statement in the employers' mind. Meeting new clients and creating the best business rapport is very important to success in the competitive IT market and an IT graduates who persuade a good personal positioning are likely to master this. Again $10 \%$ of the respondents considered that state university students are good in building their personal positioning and the rest $90 \%$ felt that private university students are better in building their personal positioning. Only 10\% of the respondents considered that state university students are good in building their personal image and the rest $90 \%$ felt that private university students are better in building their personal image.

Findings on the Personal Branding: The mediating variable personal branding was considered as one of the most influential factors of employability by all the respondents $(100 \%)$. All of them agreed the personal branding elements such as personal appearance, personality and competencies are key ingredients an IT graduate should hold to get employed at their respective IT companies. Although all the respondents consider personal branding is very important for IT graduates there are certain exceptions found in the interviews 
where $60 \%$ of the respondents mentioned that the importance of the elements of personal branding may change according to a job role. The IT graduates who sit at the back office to develop programs may not consider much about their personal appearance or personality. Thus, those who face the clients need to be well equipped with those skills since they have to meet the customer and create a good first impression of their personal appearance and personality. $40 \%$ of the respondents stated state university students pose the best personal branding and $60 \%$ of the respondents agreed private university students pose the best personal branding.

\section{Conclusion and Recommendations}

This research attempted to identify the impact of personal characteristics and personal branding of a young IT graduate on employability. Based on the literature it was found personal identity, personal image and personal positioning have an impact on employability and personal branding connects these personal characteristics with the employability of an IT graduate. The researcher mainly proved these through a quantitative analysis which is supported by the qualitative findings. A structured questionnaire was piloted among 300 young IT graduated who are employed at twenty-five IT companies in Sri Lanka. The questionnaire was based on a five point likert scale on which respondents were expected to indicate their personal characteristics, personal branding choices and employability aspects. A quantitative analysis was done for the responses received using SPSS software. In this respect a factor analysis was conducted using a factor loading and a reliability and validity tests were done to determine the consistency and validity of the questionnaire to suit the purpose of the research. According to the quantitative analysis it was proven that IT graduates have considered all three personal characteristics (personal identity, personal image and personal positioning) as important and they acquire those personal characteristics. However, it was observed that private university IT graduates have these characteristics more than the state university IT graduates. Also, they rated themselves higher in personal branding compared to the state university IT graduates.

Focusing on the indicators of personal characteristics, it was observed that state university IT graduates have low social media credibility, less positive body language, poor understanding of protocols, less willingness to network and poor awareness about personal grooming. At the same time private IT graduates showed better results in all the characteristics compared to the state university graduates. They were higher in having good practice of work ethics, having a strong belief in people, better ability to change the behavior in others and strong communications skills. With respect to the employability characteristics private sector IT graduates showed a higher result compared to the state university students. State university IT graduates were low in thinking out of the box and the private university IT graduates were better at continuous learning. Moreover, the independent variables (personal characteristics of IT graduates) such as personal identity, Personal image and personal positioning had significant positive correlation with the dependent variable (employability) and all of them were able to predict employability to a greater extent. According to the results $63 \%$ of these personal characteristics were able to predict the employability of a young IT graduate. The following formula helped in predicting the employability of an IT graduate Employability $=0.934+0.168$ (Mean of personal identity) +0.336 (Mean of personal image) +0.281 (Mean of personal positioning). A semistructured interview was conducted with ten HR / Recruitment managers who are in charge of recruiting the young IT graduates to the respective IT companies. Since, there was no empirical research carried out on personal branding on IT graduates these findings were needed to support the results received by the quantitative methods.

All the interview respondents mentioned that personal identity, personal image and personal positioning are key personal characteristics they look for in an IT graduate before recruiting them into their organization. The respondents also mentioned private university IT graduates are more adaptable and creative compared to the state university IT graduates and hence are considered more employable. Further, state university IT graduates are more passionate and goal oriented compared to the private university IT graduates thus, comparatively based on the interview findings it was concluded that the employment probability based on the skills for state university IT graduates is $47.7 \%$ and $52.3 \%$ for private university IT graduates thus, private sector IT graduates are more employable compared to the state university IT graduates. This supports the quantitative research findings. 
Recommendations: The main objective of this research study was to identify the personal characteristics and personal branding concepts that would enable the job employability of the young IT graduates. It was noted from both quantitative and qualitative analysis that these personal characteristics have a major influence in the employability. Thus, there are many shortcomings in this process. IT organizations look for IT graduates with excellent personal branding skills but the IT graduates lack certain skills which lead them to un-employability and also from the research it was concluded that private university IT graduates are stronger in their personal branding compared to state university graduates. Thus, to guide them' following recommendations are given to undergraduates, IT graduates and Universities. Undergraduates are considered as the next IT graduates who will be looking for employment in the IT companies. If they are not equipped with the personal characteristics and skills given in the personal branding framework above, it is more likely that they will not be employed in the IT companies. Therefore, they should give focus to more practical based learning, attend on-campus educational programs to improve knowledge and skills.

They should do other certifications apart from the academic modules to improve technical competencies, dedicate for continuous learning by attending workshops, seminars and training to improve skills, get engaged with paid/unpaid internships to improve competencies, professionalism, creativity, practice and adaptability, get engaged in clubs, associations, societies, overseas transferring programs, volunteering work to build self-efficacy, personality, and to build networks. Moreover, the undergraduate students should take part in networking events, seminars on personal branding and improve number of connections, build communication skills by enrolling in toastmaster's clubs, interactive clubs and literary associations and build online brand presence by engaging in social media channels and other digital mediums (online blogs, online videos, linked in and online networks). If the IT graduates are concerned that they should be aware of their skills, competencies, personality and personal characteristics, be aware of the personal characteristics that are necessary for the specific job role applied in the IT Company and compare the skills needed with the skills owned, they should improve the personal grooming aspects and power dressing techniques.

Networking is key in building the personal brand therefore, they should attend networking events, to build contacts. Furthermore, they should attend training, seminars and workshops on personal branding, management skills development and communication skills to improve the employability. As clearly mentioned in the first chapter, Sri Lanka is facing an issue in unemployment for quite a few years. Poor personal characteristics and personal branding lead to this scenario. From the interviews conducted it was noted that IT companies consider private university IT graduates are more employable than the state university IT graduates. This arrangement will help them to find employment opportunities in best IT companies. The universities should encourage undergraduates to take part in IT related local/global competitions such as National Best Quality Software Awards (NBQSA), Microsoft Imaging Cup, Student prenuer (Student Entre prenuer) of the year award, IEEE competitions etc. This will improve their competencies and their networks. Moreover, get the students into tech entrepreneurship ventures that will build their personal characteristics and personal branding and in return they will learn a lot from industry experts and be ready for employment.

\section{References}

Aaker, D. A. (2002). Brand leadership: Building assets in an information economy. New York: Simon \& Schuster.

Ariyawansa, R. (2008). Employability of Graduates of Sri Lankan Universities. Sri Lankan Journal of Human Resource Management, 2(192).

Cresswell, J. W. (2014). Research Design: Quantitative and Mixed Method Approaches (4th ed.). United States: SAGE Publications.

Dissanayake, M. (2014). High university enrolment, low graduate employment Analysing the paradox. Retrieved from Dissanayake, M. (2014). High university enrolment, low graduate employment Analysing the paradox.

Gunatatna, S. (2017). Sri Lanka: Sri Lanka\'s economic growth at 4.0\% in Q2 2017 despite impact of inclement weather.

Hair, J. F., Christian, M. \& Marco, S. (2011). PLS-SEM: Indeed a Silver Bullet. Journal of Marketing, 139-151.

Hillgren, G. C. (2011). The authenticity of personal Branding. Department of Business Administration. 
Hollenbeck, C. R. \& Kaikati, A. M. (2012). Consumers' use of brands to reflect their actual and ideal selves on Facebook, International Journal of Research in Marketing, 29 (4) ), 395-405.

Kapurubandara, M. (2016). Graduates in the 21st Century.

Labrecque, L. M. (2011). Online personal Branding: Processes, challenges, and implications. Journal of Interactive Marketing, 25(1).

Miester, J. (2012). Retrieved from http://www.forbes.com/sites/jeannemeister/2012/12/04/personalbranding-in-the-futureworkplace-a-crucial-skill-for-employees.

Montoya, P. (2002). The Personal Branding Phenomenon. Retrieved from Personal Branding Press.

Parmentier, M., Fischer, E. \& Reuber, A. R. (2012). Positioning person brands in established organizational fields. Journal of the Academy of Marketing Science, 373-387.

Paul, H. (2012). Personal Branding- key career skill in the future workplace.

Rampersad, H. (2011). Body of Knowledge. Operational Excellence Society. How to build an authentic personal brand.

Sanderatne, N. (2011). Unemployment, unemployed and the unemployable.

Saunders, M., Lewis, P. \& Thornhill, A. (2013). Research Methods for Business Students (5th ed.). India: Dorling Kindersley.

Schawbel, D. (2010). Steps to building your Future. United States: Kaplan Trade.

Sekeran, U. \& Bougie, R. (2016). Research Methods for Business. A Skill Building Approach. India: Wiley India Pvt ltd.

Shepherd, I. (2005). From cattle and coke to Charlie: Meeting the challenge of self-marketing and Meeting the challenge of self-marketing and personal Branding. Journal of Marketing Management, 21 (5-6), Informa UK, 589-606. Retrieved from https://eprints.mdx.ac.uk/6582/1/Shepherdfrom_cattle_and

Srilankamirror.com. (2016).

SullaivanLair, D. J. \& Cheney. (2005). Marketization and the Recasting of the professional selfTAvailable from https://www.researchgate. The rhetoric and ethics of personal Branding. Management Communication Quarterly, 18 (3).

Tharamaseelan, N. (2007). Tertiary Education in Sri Lanka; Issues and Challenges. Bulgarian Journal of Science and Education Policy (BJSEP), 173-190.

Towson, M. (2015). Competency Crisis? Many Young Professionals Lack Training in Vital "Soft Skills". Retrieved from Towson, M.. (2015).

Usrey, C. \& Sargent, A. (2013). Networking and Personal Branding E- GUIDE.

Weiss, B. \& Felderman, R. S. (2006). Looking good and lying to do it: Deception as an impression management strategy in job interviews. Journal of Applied Social Psychology, 36 (4). 